\title{
Distribution and morphology of two helminths recently introduced into European eel populations: Anguillicola crassus (Nematoda, Dracunculoidea) and Paratenuisentis ambiguus (Acanthocephala, Tenuisentidae)
}

\author{
Horst Taraschewski ${ }^{1}$, František Moravec ${ }^{2}$, Theophile Lamah ${ }^{1}$, Kerstin Anders ${ }^{3}$ \\ ${ }^{1}$ Institut für Spezielle Zoologie und Parasitologie, Ruhr-Universität-Bochum, D-4630 Bochum, Federal Republic of Germany \\ ${ }^{2}$ Institute of Parasitology, Czechoslovak Academy of Sciences, České Budějovice, Czechoslovakia \\ ${ }^{3}$ Institut für Meereskunde, Universität Kiel, D-2300 Kiel, Federal Republic of Germany
}

\begin{abstract}
The occurrence of 2 helminths is reported in eel from 3 regions of the Federal Republic of Germany. Both species, Anguillicola crassus (Nematoda, Dracunculoidea) and Paratenuisentis ambiguus (Acanthocephala, Tenuisentidae) were recently introduced into Europe, probably from Japan and the USA, respectively. The morphology of $A$. crassus differs from the original description in a few features. Syntype specimens from Japan, however, showed that specimens from Japan and from Germany are conspecific. The morphology of $P$. ambiguus (first report from Europe) corresponds well with the original description from North America. In Germany it is shown to employ the same crustacean intermediate host as in North America, i.e. Gammarus tigrinus, an amphipod originally introduced purposely into Germany.
\end{abstract}

\section{INTRODUCTION}

In recent years several allochthonous helminths of eel have invaded Europe. Two species of the conspicuously large swim-bladder nematodes of the genus Anguillicola have been recently found in Italy (Paggi et al. 1982) and Central Europe, e.g. Germany (Neumann 1985, Peters \& Hartmann 1986), the Netherlands (Van Banning et al. 1985) and Denmark (Køie 1988). The species occurring in Italy had been identified as $A$. australiensis (Paggi et al. 1982) but has now been described as $A$. novaezelandiae sp. nov., a species endemic to New Zealand (Moravec \& Taraschewski 1988). Until now Anguillicola species from Australia (Johnston \& Mawson 1940, Rid 1973) and New Zealand (Hine 1978) had not been distinguished as separate species. The species occurring in Central Europe has been suspected to be A. crassus (Van Banning et al. 1985), a species infecting eels in East Asia (Kuwahara et al. 1974), and earlier wrongly identified as $A$. globiceps by Egusa et al. (1969). Peters \& Hartmann
(1986) emphasized, however, that its morphology did not correspond with any of the described Anguillicola species. Three other Anguillicola species, indigenous to East Asia, Australia and southern Africa, respectively (Moravec \& Taraschewski 1988) have not to date been reported in Europe.

The intestinal acanthocephalan Paratenuisentis ambiguus is known as an endemic eel parasite of brackish waters along the east coast of the USA (Bullock \& Samuel 1975). It has not previously been recorded from outside the USA. In the present communication, distribution and morphology of these 2 helminths (Anguillicola crassus and $P$. ambiguus), introduced into European eel populations is reported. Further, the first intermediate host of $P$. ambiguus in European waters is identified.

\footnotetext{
The species had been described as A. crassa by Kuwahara et al. (1974) but is now named $A$. crassus by Moravec \& Taraschewski (1988)
} 


\section{MATERIALS AND METHODS}

Sampling and examinations of eels. Naturally infected eels Anguilla anguilla were obtained in the Federal Republic of Germany from a lake on the River Ruhr (Kemnader See) (Str 1), River Weser (Stn 2) and Elbe estuary (Stns 3A to C) (Fig. 1). In the Elbe estuary eels were obtained from 3 sampling areas: the inner 'estuary' between Hamburg and Stadersand with a salinity of $<1 \%$, the middle estuary between Stadersand and Brunsbüttelkoog with salinities fluctuating between 0 and $15 \%$ and the outer estuary between Brunsbüttelkoog and Cuxhaven-Duhnen with salinities between 15 and $30 \%$ (Möller 1984). Most eels were transferred alive to the laboratory at Bochum, kept in aquaria for up to $7 \mathrm{~d}$, fed with defrosted liver and then killed. The viscera were removed immediately and checked for helminths. Eels from the Elbe estuary were

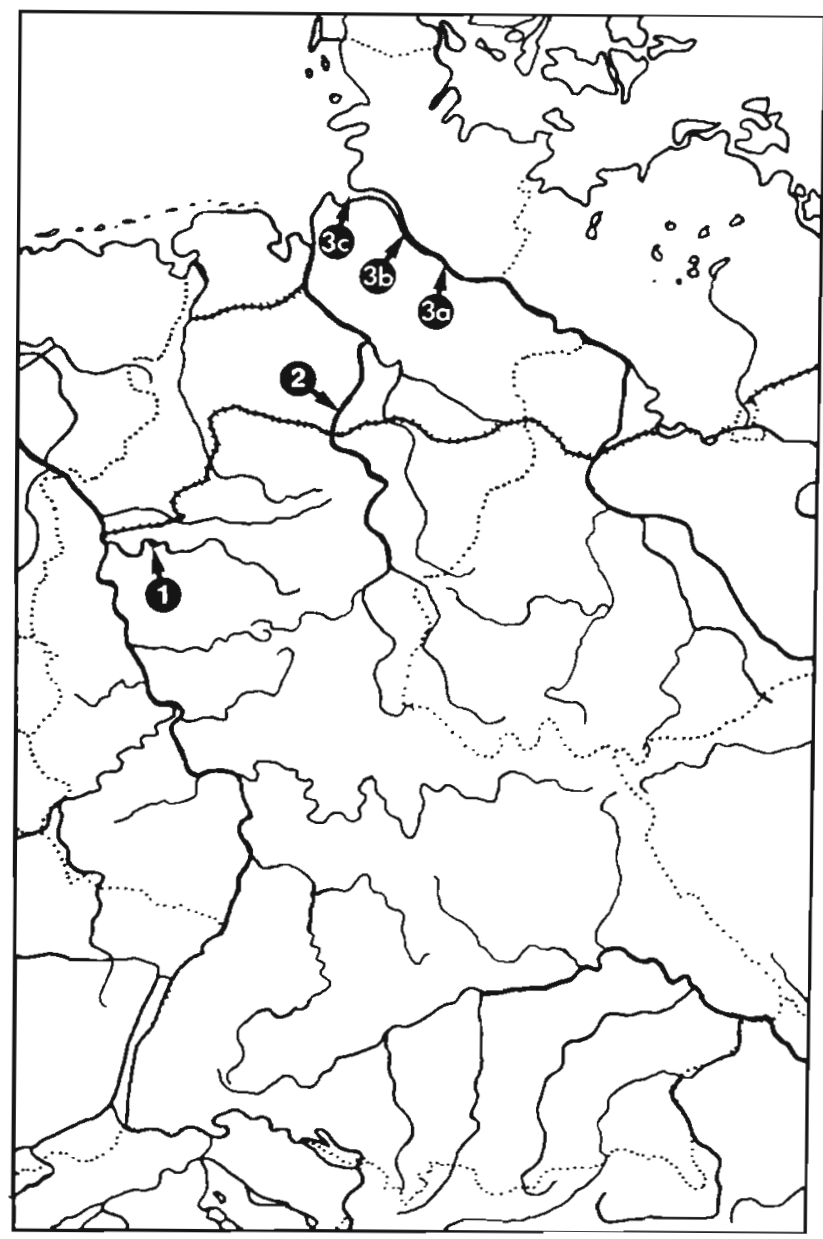

Fig. 1. Map of FR Germany, showing main inland waters and the sampling stations. Stn 1: Ruhr lake (Kemnader See) near Bochum; Stn 2: River Weser near Petershagen/Schlüsselburg; Stn 3a: Lower Elbe river near Hamburg; Stn 3b: inner Elbe estuary; Stn 3c: outer Elbe estuary also killed on board the fishery vessel, opened, and fixed in $4 \%$ formaldehyde, but were only used for quantitative evaluations.

Processing of the worms. Worms collected from the freshly opened eels were processed as follows:

Micrographs were made from live specimens kept in saline (Fig, 4 A, B, D, E). Measurements of Anguillicola crassus were made from worms fixed in cold $10 \%$ ethanol and transferred into graded glycerine, using a measuring binocular microscope. Drawings (Fig. 2) and measurements are based on means of 10 worms. Type specimens of $A$. crassus were obtained from the Meguro Parasitological Museum, Tokyo (Cat. No. 193093). Non-type specimens of Japanese A. crassus, A. globiceps and Italian A. novaezelandiae were obtained by courtesy of Prof. Lia Paggi, Univ. of Rome.

Specimens of Paratenuisentis ambiguus were relaxed overnight in chilled tap water, fixed in $10 \%$ formalin and then transferred to $70 \%$ ethanol. Methylene-blue was used for staining, $\mathrm{HCl}$-ethanol for differentiation. Worms were dehydrated in graded ethanol, cleared in cedar-wood oil, embedded in Entelan and measured using a microscope. For drawings of $P$. ambiguus see Bullock \& Samuel (1975) and Samuel \& Bullock (1981). However, the photographs of the sexual organs, presented here, give more detailed information. Type specimens of $P$. ambiguus were obtained from the U.S. National Museum, Washington, D. C. (USNM, Nos. 6301, 6471, 72905, 72906).

For scanning electron microscopy (SEM) (Figs. 3 and $4 \mathrm{C}$ ) worms were fixed in $5 \%$ glutaraldehyde buffered with $0.1 \mathrm{M}$ sodium cacodylate, and postfixed in $2 \%$ $\mathrm{OsO}_{4}$ in the same buffer. After dehydration in graded acetone they were transferred to liquid $\mathrm{CO}_{2}$ and critical-point dried, then mounted on metal stubs and sputtered with gold in a SEM-coating unit E5100 (Polaron Equipment). The parasites were examined with a Super-3-A SEM (Intemational Scientific Instruments).

Sampling of the acanthocephalan intermediate host and transmission trials. After finding large numbers of Paratenuisentis ambiguus in eel from the River Weser, the only abundant species of higher crustacean, namely the amphipod Gammarus tigrinus Sexton, was sampled from the river by means of a net. Medium sized amphipods ( 0.8 to $1 \mathrm{~mm}$ in length) were transferred to the laboratory, squeezed and checked for acanthocephalan larvae (Fig. 4E) under a binocular microscope. During early March 1986 about 30 adult amphipods sampled from the river were brought to the laboratory alive, first kept in Weser river water and then gradually transferred to aquarium water of $5 \%$ salinity. They were fed with fish- and rat-pellets. Their F1-offspring were tested for experimental infection with mature eggs of $P$. ambiguus as described by Taraschewski (1985), and then kept at $22^{\circ} \mathrm{C}$. Stickle- 
backs Gasterosteus aculeatus were used for the determination of infectivity of the acanthocephalan larvae within the amphipods

\section{RESULTS}

\section{Field data, laboratory cycle}

For the results of the survey see Table 1 and Fig. 1 . A correlation between eel length and infection by either of the 2 helminths was not apparent in the sampled size group.

Anguillicola crassus was highly abundant in the Ruhr lake. Prevalence and intensity of infection increased from 1986 to 1987 . In the River Weser prevalence (only 1986 data available) was lower. In the Elbe estuary infection by $A$. crassus was lowest (only 1986 data available) and declined from sampling area $3 \mathrm{~A}$ to $3 \mathrm{C}$ (Table 1).

Paratenuisentis ambiguus did not occur in the Ruhr lake. In the River Weser most eels were infected, with a mean of 98.2 worms per eel. One worm was found in a single eel of the Elbe estuary. In the River Weser $26.5 \%$ of the sampled Gammarus tigrinus were infected by $P$. ambiguus. G. tigrinus did not occur in the other 2 waters. The experimentally infected $G$. tigrinus harboured 1 to 3 larvae per amphipod which were infectious for sticklebacks from the 34 th day postinfection.

\section{Morphology}

Anguillicola crassus Kuwahara et al., 1974. The description of $A$. crassus presented here is restricted to features seen by light microscope (LM) or SEM that were not described by Kuwahara et al. (1974) or are contradictory to the original description, which only included LM studies (Figs. 2 and 3; Table 2). The worms have a soft wrinkled outer cuticle (Fig. 3C, D, E) that covers the whole body The circular mouth aperture is small so that only a few host's erythrocytes can pass into it at the same time (Fig. 3A); it is surrounded by 4 dorsolateral and ventrolateral cephalic papillae and 2 small lateral amphids (Fig. 3C). The anterior rim of the buccal capsule bears one row of 22,24, 26 or 28 circumoral teeth (Fig. 3C). The oesophagus appears strongly muscular, consisting of 3 lobes, expanding at its posterior half (Fig. 2A, B, G and 3B); anteriorly, the oesophagus forms 6 slightly elevated, rounded lobes protruding into the buccal cavity (Fig. 3B). The valvular apparatus of the oesophagus is well developed (Fig. $2 \mathrm{~A}, \mathrm{~B}, \mathrm{G})$. Male worms have 6 pairs of caudal papillae: 2 praeanals, 1 or 2 adanals and 2 or 3 postanals (Figs. 2C, D, E and 3D).

Paratenuisentis ambiguus (Van Cleave, 1921) Bullock \& Samuel, 1975 belongs to the monospecific genus Paratenuisentis (Tenuisentidae, Eoacanthocephala). It has a prominent apical organ, often seen as a conspicuous elevation of the proboscis tip (Fig. 4E), posteriorly extending to the fourth circle of hooks. For all other features see Table 3, Fig. 4 and Bullock \& Samuel (1975). The lengths of the lemnisci in males from Germany were almost equal, while a slight difference in length was measured in females. Bullock \& Samuel (1975) considered the lemnisci as subequal and thus differentiated between a 'long' and a 'short' lemniscus (Table 3). In the present investigation both lemnisci often lay twisted at the worm's ventral side making their measurement difficult. Infective larvae

Table 1 Prevalences of Anguillicola crassus and Paratenuisentis ambiguus in eels, and Gammarus tigrinus in 3 waters of F. R. Germany

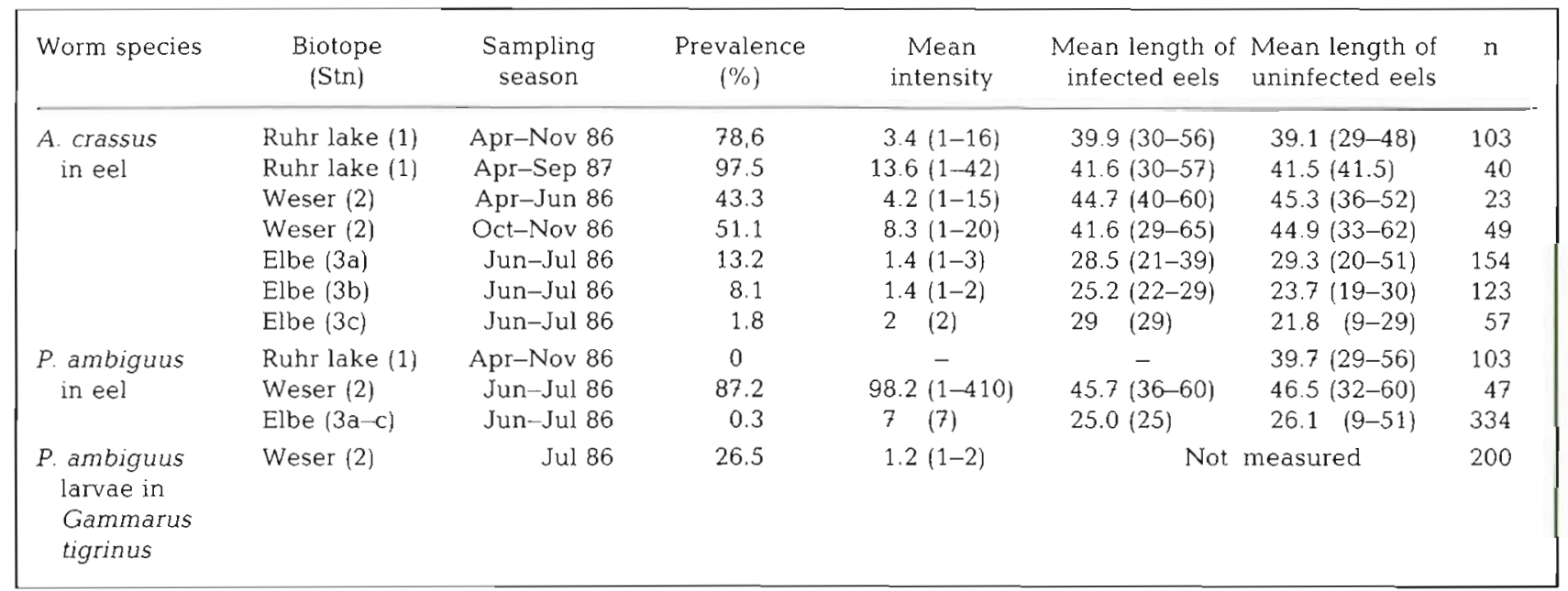




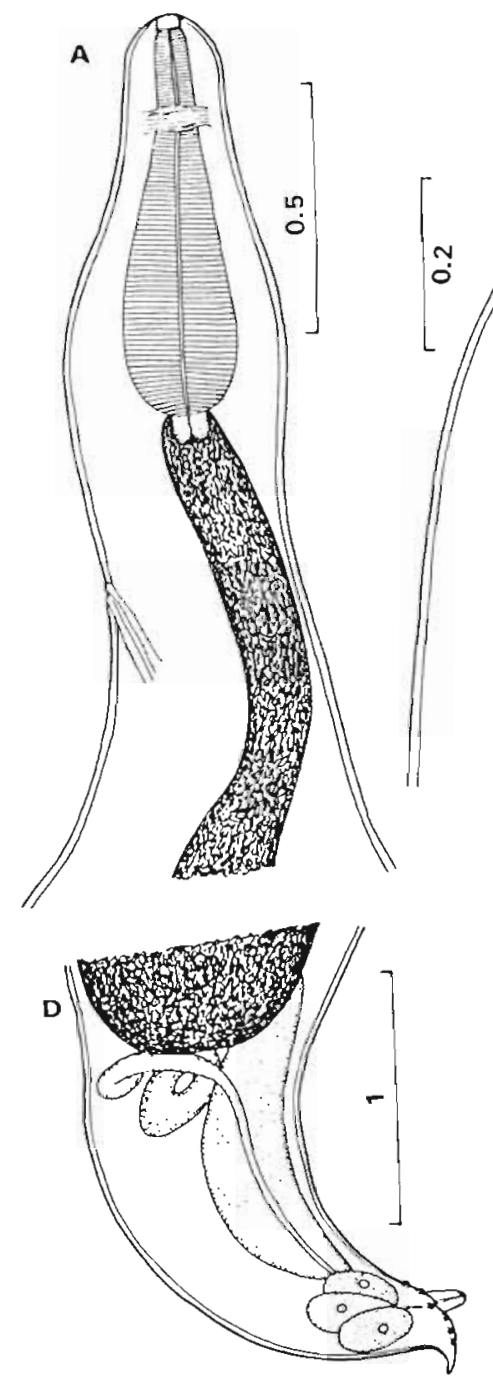

E
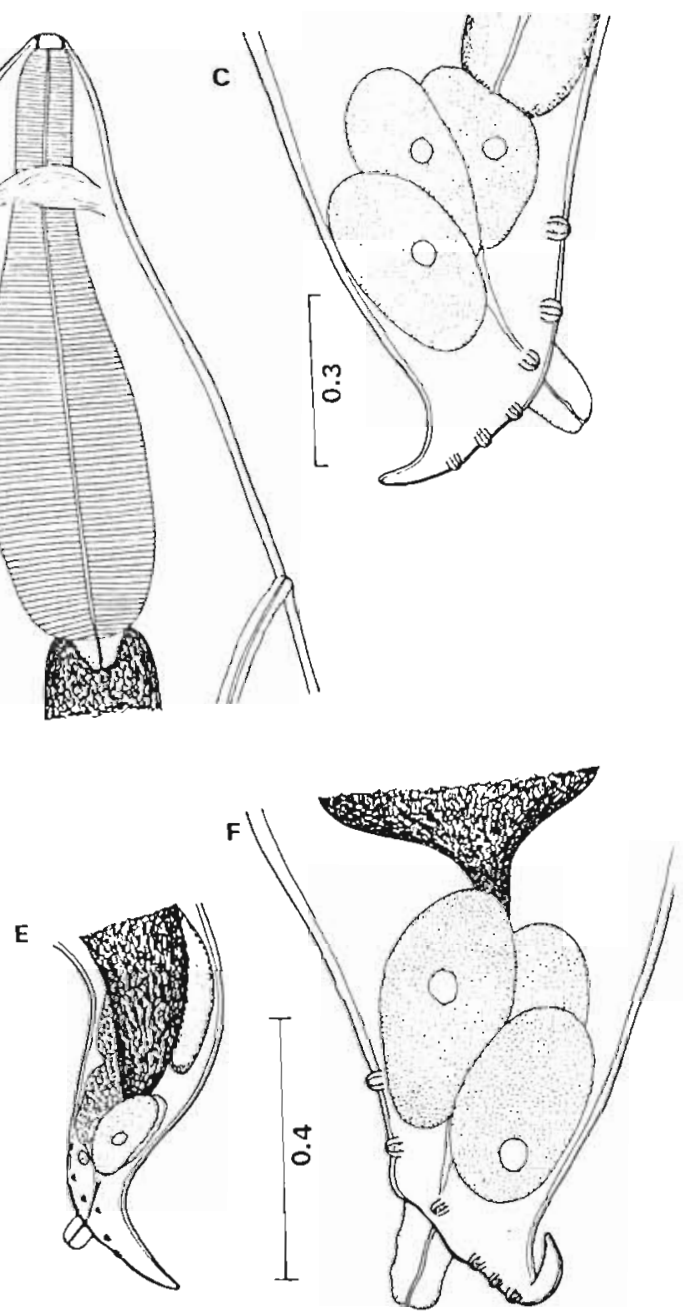
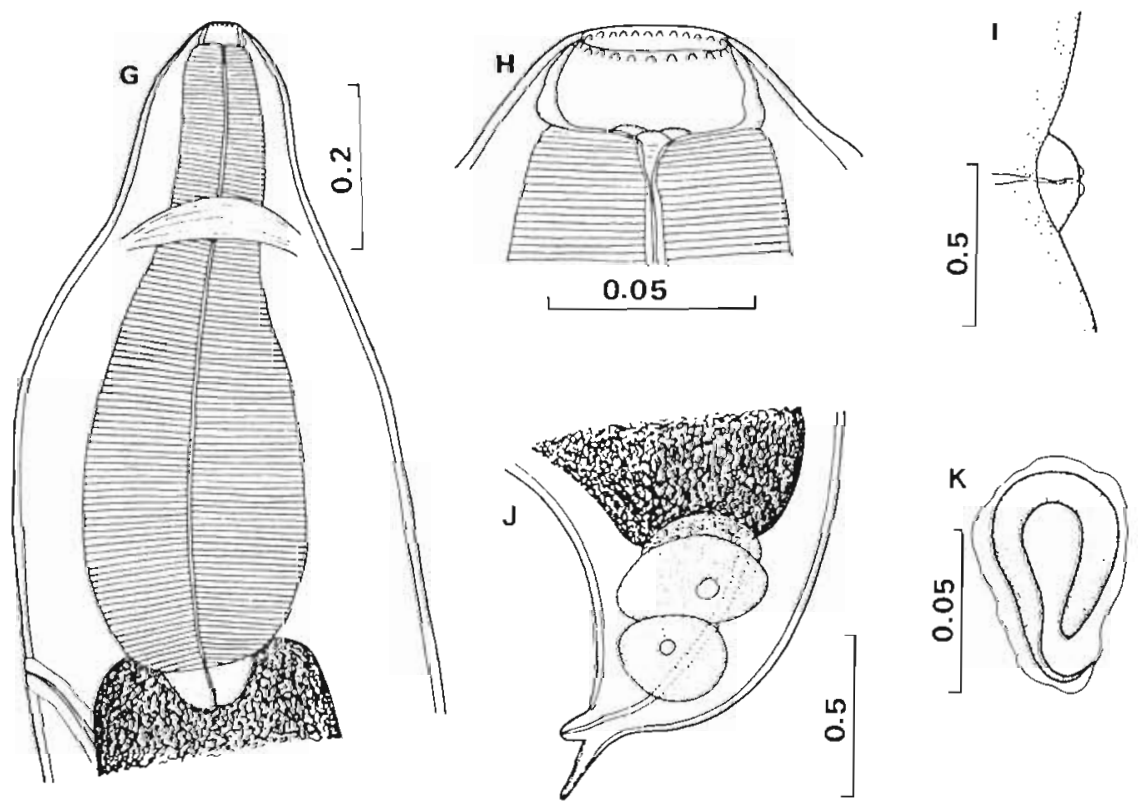

Fig. 2. Anguillicola crassus. Important features of male (A to $\mathrm{F}$ ) and female ( $G$ to $K$ ) worms. Male: (A) anterior end of specimen with narrowed body in the oesophagial region; ( $B$ ) head end, usual shape; $(C, D)$ caudal end; $(E, F)$ caudal ends of small and large males (same magnification). Female: (G) head end of largest specimen; $(\mathrm{H})$ buccal capsule; (I) vulva; (J) caudal end; (K) sheathed larva from uterus. All scales in $\mathrm{mm}$ 
Table 2. Anguillicola crassus. Comparison of specimens from Japan and Europe. $\mathrm{n}=10$ (except types)

\begin{tabular}{|c|c|c|c|c|c|c|}
\hline \multirow[b]{2}{*}{ Measurement (mm) } & \multicolumn{2}{|c|}{$\begin{array}{c}\text { Type specimens } \\
\text { after Kuwahara et al. } 1974 \\
\text { (Own measurements in brackets) }\end{array}$} & \multicolumn{2}{|c|}{$\begin{array}{l}\text { Non-type specimens from } \\
\text { Japan (new data) }\end{array}$} & \multicolumn{2}{|c|}{$\begin{array}{l}\text { European specimens } \\
\text { (present material) }\end{array}$} \\
\hline & $\delta$ & 9 & 8 & P & 3 & $q$ \\
\hline Body length & $\begin{array}{l}20.5-55.9 \\
(32.94)\end{array}$ & $\begin{array}{c}47.1-71.5 \\
(42.94)\end{array}$ & $12.92-21.76$ & $30.87-44.74$ & $5.77-23.12$ & $16.23-36.72$ \\
\hline Body width & $\begin{array}{l}0.9-2.8 \\
(3.7)\end{array}$ & $\begin{array}{l}3.0-5.6 \\
(4.7)\end{array}$ & $0.816-1.02$ & $1.63-3.50$ & $0.340-1.77$ & $1.36-5.00$ \\
\hline $\begin{array}{l}\text { Length of buccal } \\
\text { capsule }\end{array}$ & $\begin{array}{c}0.015-0.025 \\
(0.024)\end{array}$ & $\begin{array}{l}0.018-0.028 \\
(0.027)\end{array}$ & $0.021-0.027$ & 0.027 & $0.021-0.027$ & $0.024-0.027$ \\
\hline $\begin{array}{l}\text { Width of buccal } \\
\text { capsule }\end{array}$ & $\begin{array}{c}0.045-0.060 \\
(0.048)\end{array}$ & $\begin{array}{c}0.045-0.060 \\
(0.054)\end{array}$ & $0.048-0.060$ & $0.060-0.063$ & $0.048-0.057$ & $0.054-0.063$ \\
\hline $\begin{array}{l}\text { Length of } \\
\text { oesophagus }\end{array}$ & $\begin{array}{l}0.68-1.03 \\
(0.76)\end{array}$ & $\begin{array}{c}0.86-1.10 \\
(0.98)\end{array}$ & $0.775-0.843$ & $0.911-1.09$ & $0.571-0.816$ & $0.775-1.06$ \\
\hline $\begin{array}{l}\text { Max. width of } \\
\text { oesophagus }\end{array}$ & $\begin{array}{l}0.24-0.41 \\
(0.26)\end{array}$ & $\begin{array}{l}0.30-0.49 \\
(0.33)\end{array}$ & $0.207-0.218$ & $0.231-0.272$ & $0.135-0.258$ & $0.258-0.381$ \\
\hline $\begin{array}{l}\text { Length ratio of } \\
\text { oesophagus } \\
\text { and body }\end{array}$ & $\begin{array}{c}1: 27.0-69.0 \\
(1: 43.3)\end{array}$ & $\begin{array}{c}1: 39.0-65.9 \\
(1: 43.7)\end{array}$ & $1: 16.7-25.8$ & $1: 33.9-41.1$ & $1: 10.1-29.2$ & $1: 20.9-34.6$ \\
\hline $\begin{array}{l}\text { No. of caudal } \\
\text { papillae in male }\end{array}$ & $5(6)$ & - & $5-6$ & - & 6 & - \\
\hline $\begin{array}{l}\text { Distance of vulva } \\
\text { from posterior end }\end{array}$ & - & $\begin{array}{l}8.40-12.25 \\
(?)\end{array}$ & - & $4.08-4.90$ & - & $4.01-7.01$ \\
\hline Length of tail & $?(0.207)$ & $?(0.231)$ & $0.215-0.240$ & 0.299 & $0.120-0.286$ & $0.136-0.448$ \\
\hline Hosts & \multicolumn{2}{|c|}{$\begin{array}{l}\text { Anguilla anguilla } \\
\text { Anguilla japonica }\end{array}$} & \multicolumn{2}{|c|}{ Anguilla anguilla } & \multicolumn{2}{|c|}{ Anguilla anguilla } \\
\hline Occurrence & \multicolumn{2}{|l|}{ Japan } & \multicolumn{2}{|c|}{ Japan } & \multicolumn{2}{|c|}{ FR Germany } \\
\hline
\end{tabular}

(Fig. 4E) from the intermediate host were very similar to those described from North America by Samuel \& Bullock (1981).

\section{DISCUSSION}

\section{Morphology}

Specimens of Anguillicola crassus from Germany differed from those from Japan described by Kuwahara et al. (1974) in their somewhat smaller body sizes, slight differences in the shape of the oesophageal region, the presence of 6 pairs of caudal papillae in the male, in contrast to 5 , and the presence of a fourth (small) rectal gland (Fig. 2E) similar to that described by Yamaguti (1935) for A. globiceps. The different proportions seem to be due to different fixation (hot formalin versus cold formalin) and to allometric growth of the worms. The Japanese investigators did not use SEM and they probably missed the sixth pair of caudal papillae and the fourth rectal gland which is often overlapped by the 3 larger ones. A revision of the type specimens from Japan showed that they also carried 6 pairs of caudal papillae and a fourth rectal gland, like the European specimens.

Concerning Paratenuisentis ambiguus, measurements obtained from European specimens fall within the range of sizes given for the American specimens. Mean values for the American specimens, however, were not presented by Bullock \& Samuel (1975). Thus, it cannot be decided - even considering the American type specimens - whether the lemnisci of the American worms were more subequal than those of the European ones.

Taking all features into consideration, there are no doubts about the conspecificity of the European and the Japanese specimens of Anguillicola crassus, and the European and the American specimens of $P$. ambiguus.

\section{Field data, laboratory cycle}

European eels have been helminthologically examined since the end of the eighteenth century and are still being investigated constantly. It can be concluded that any new helminth species is reported fairly 

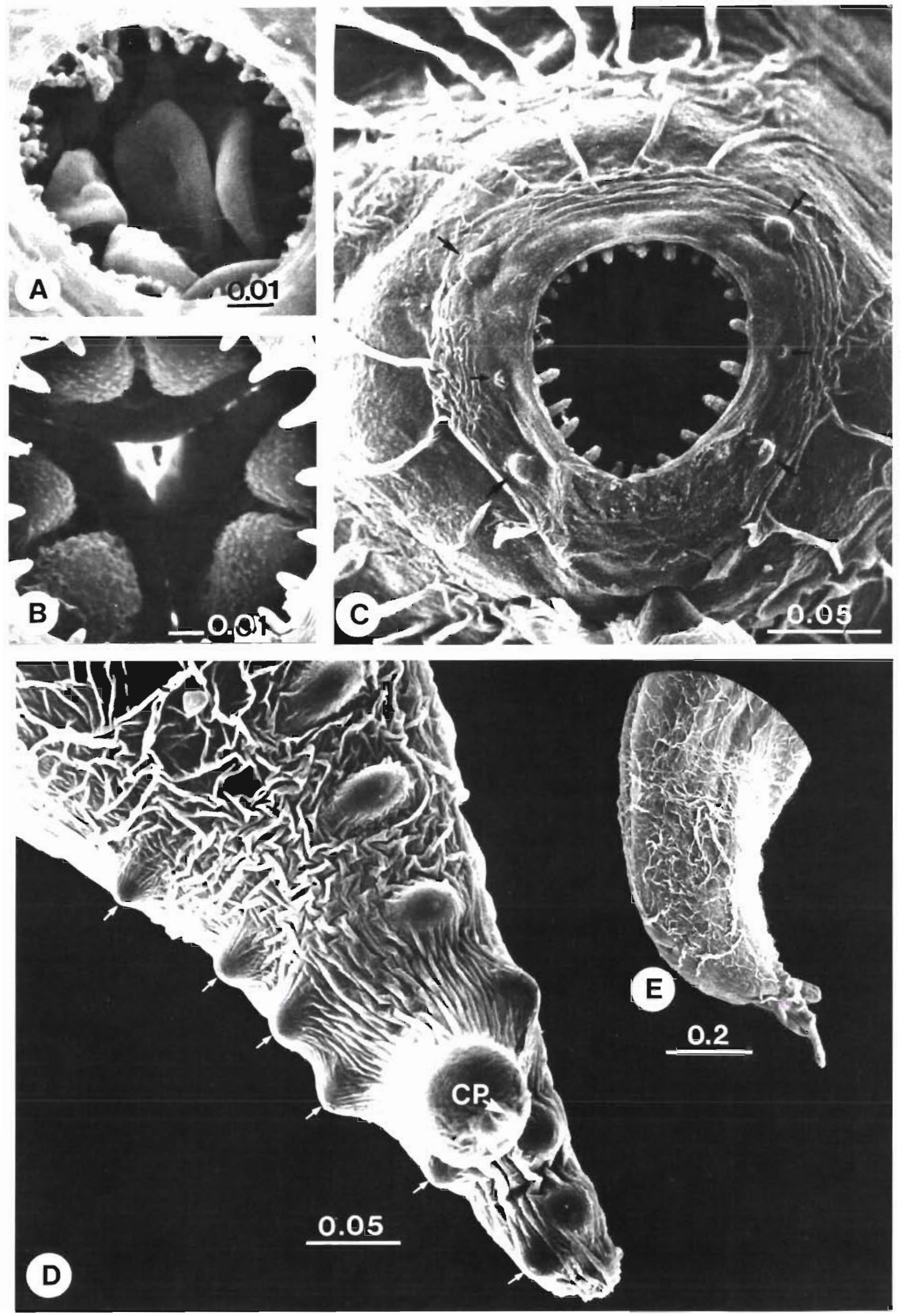
Table 3. Paratenuisentis ambiguus. Morphological data. Measurements in $\mu \mathrm{m}$, except worm length which is in $\mathrm{mm}$ (mean in brackets); $\mathrm{n}=10$

\begin{tabular}{|c|c|c|c|c|c|}
\hline Females & $\begin{array}{c}\text { Bullock \& Samuel } \\
1975^{\circ}\end{array}$ & Present study & Males & $\begin{array}{c}\text { Bullock \& Samuel } \\
1975^{\circ}\end{array}$ & Present study \\
\hline Length & $4.4-13.7$ & $6.8 .-11(8.2)$ & As females & $2.7-8.1$ & $4.7-6.5(5.6)$ \\
\hline Maximal width & $410-1520$ & $504-990(682)$ & As females & $330-1010$ & $522-792(621)$ \\
\hline Length of external praesoma & $620-848$ & $684-810(752)$ & As females & $440-680$ & $594-699(655)$ \\
\hline Max. width of ext praesoma & $120-210$ & $140-200(166)$ & As females & $100-170$ & $144-180(160)$ \\
\hline No. proboscis hooks per row & $13-17$ & $14-17(15.7)$ & As females & $11-17$ & $13-16(14.1)$ \\
\hline No. of hook rows & $18-22$ & $16-19(17.9)$ & As females & $14-18$ & $14-17(15.3)$ \\
\hline Size of anterior hooks & $40-55 \times 8-11$ & $\begin{array}{c}40-50 \times 7-11 \\
(44.7 \times 9.3)\end{array}$ & As females & $43-50 \times 8-11$ & $\begin{array}{c}43-50 \times 9-11 \\
(46 \times 9.8)\end{array}$ \\
\hline Size of posterior hooks & $36-48 \times 5-8$ & $\begin{array}{c}36-45 \times 5-7 \\
(38.6 \times 6.8)\end{array}$ & As females & $38-47 \times 5-7$ & $\begin{array}{c}34-40 \times 5-7 \\
(38 \times 6.3)\end{array}$ \\
\hline Length of receptacle & $390-1200$ & $864-1080(995)$ & As females & $330-950$ & $756-990(869.6)$ \\
\hline Length of long lemniscus & $860-2490$ & $1550-2340(1780)$ & As females & $630-2730$ & $1422-1980(1588)$ \\
\hline Length of short lemniscus & $750-2100$ & $1260-1980(1630)$ & As females & $590-2640$ & $1386-1944(1559)$ \\
\hline Length of vagina & $130-210$ & $144-198(167)$ & $\begin{array}{l}\text { Length of } \\
\text { anterior testis }\end{array}$ & $220-850$ & $360-720(482.4)$ \\
\hline Length of uterus & $140-390$ & $207-324(262)$ & $\begin{array}{l}\text { Length of } \\
\text { posterior testis }\end{array}$ & $210-1040$ & $468-900(631.8)$ \\
\hline $\begin{array}{l}\text { Length of uterine bell } \\
\text { \& apparatus }\end{array}$ & $130-520$ & $198-324(238)$ & $\begin{array}{l}\text { No. of cement } \\
\text { gland nuclei }\end{array}$ & $26-48$ & $30-43$ \\
\hline Size of mature eggs (saline) & $62-72 \times 26-31$ & $\begin{array}{c}64-71 \times 26-30 \\
(67 \times 29)\end{array}$ & $\begin{array}{c}\text { Length of } \\
\text { cement reservoir }\end{array}$ & $70-350$ & $216-306(256)$ \\
\hline Hosts & Anguilla rostrata & Anguilla anguilla & As females & As females & As females \\
\hline Occurrence & USA & FR Germany & As females & Asfernales & As females \\
\hline
\end{tabular}

soon after its appearance. Thus, both new helminths must have invaded Europe within the last few years, probably with intercontinental live eel transports.

In this investigation Anguillicola crassus was found already widely distributed in diverse habitats in northern Germany: it was abundant in the eutrophic Ruhr lake (Stn 1) as well as in the low salinity (see Veh 1975) Weser river (Stn 2) and the mixohaline (see Moller 1984) Elbe estuary (Stns 3A to 3C). The wide distribution is probably assisted by a broad range of intermediate hosts or by being transmitted by ubiquitous intermediate hosts. The East Asiatic congeneric A. globiceps developed in various copepods and cladoceran intermediate hosts (Haung 1981). Only 2 copepods were tested as intermediate hosts of $A$. crassus in Japan: one was positive, one refractory (Hirose et al. 1976). Differences in prevalence in various localities may result from many factors including a different abundance of infected intermediate hosts. Transmission appears to be restricted to freshwater or low-salinity environments as can be seen from the decrease in infection towards the open sea in the Elbe estuary (Table 1). The increase of infection, especially in intensity, in the Ruhr lake from 1986 to 1987 is conspicuous. During summer 1987 local fishermen complained about a striking decrease of the eel catch. Several dead eels were found. Prior to 1986 eels from Ruhr lake were investigated only for their intestinal parasites. Nevertheless, large worms inside the air-bladder would have been noticed. Thus, it can be concluded that the prevalence and intensity of infection in that habitat must have been much lower before 1986 . Whether there is a connection between the decreasing catch and the increasing abundance of $A$. crassus remains uncertain

Fig. 3. Anguillicola crassus. SEM-micrographs of important outer features. (A) Mouth opening with enclosed erythrocytes of eel host; (B) empty mouth showing the buccal cavity with 6 slightly elevated lobes that posteriorly transgrade into the 3 prominent oesophagial lobes; (C) mouth opening with circumoral teeth and surrounding 4 dorsolateral cephalic papillae (large arrows) and 2 lateral amphids (small arrows); (D) frontal view of caudal end of male showing 6 pairs of caudal papillae (arrows) and cloacal core (CP) on top of the cone-shaped vental process; note the wrinkled upper layer of cuticle that surrounds the worm; (E) lateral view of male caudal end. All scales in $\mathrm{mm}$ 


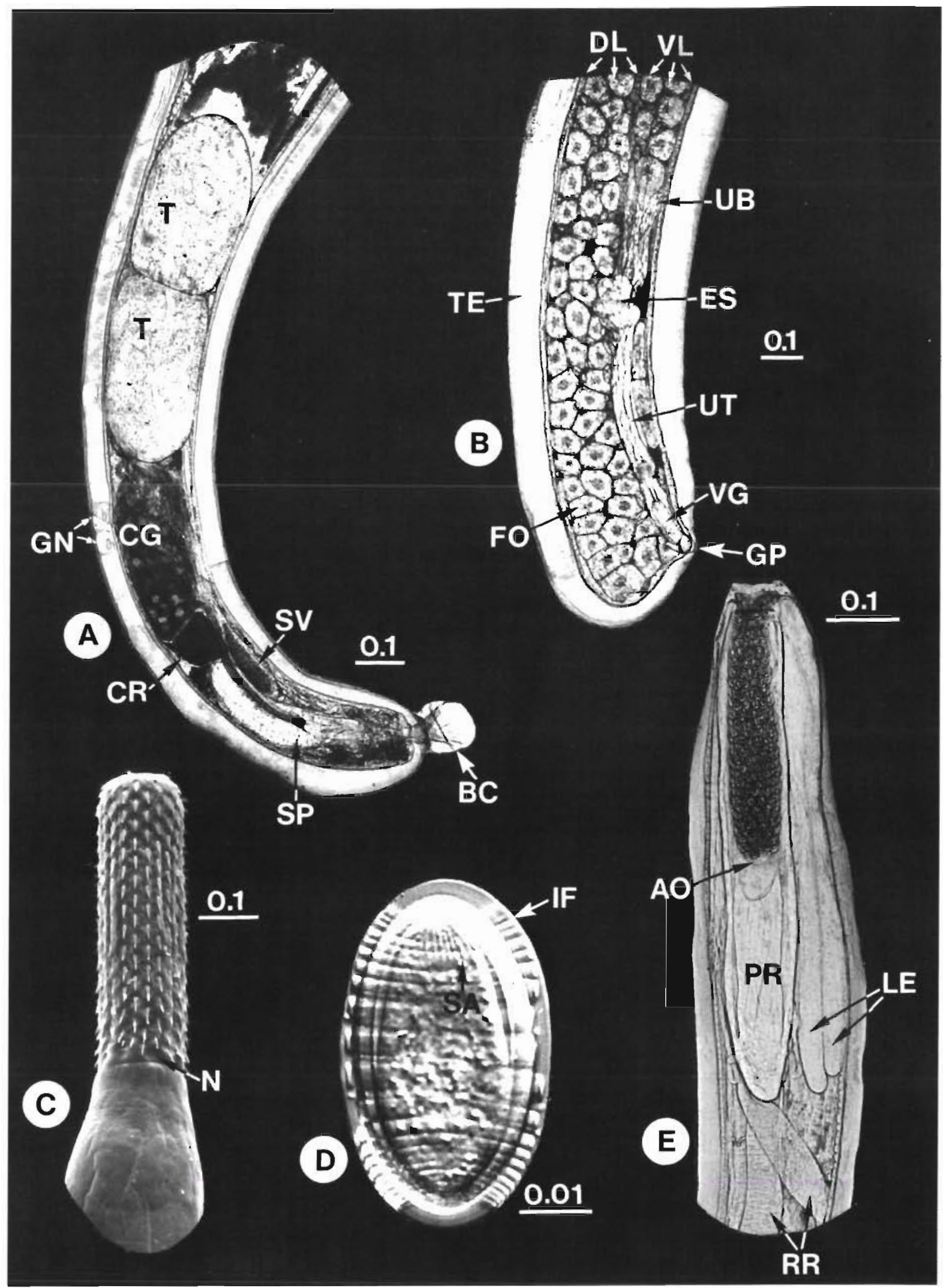

Fig. 4. Paratenuisentis ambigurus. (A, B, D, E) LM and (C) SEM micrographs of important features. (A) Posterior half of male, showing the sexual organs; the bursa copulatrix $(B C)$ is evaginated; $(B)$ posterior portion (posterior eighth) of female, with enclosed sexual organs; note that the ventral ligament sac (VL) terminates in the uterine bell (UB) while the dorsal sac (DL) encloses most of the uterus (UT) and vagina; (C) praesoma (proboscis and very narrow neck) showing the proboscis hooks arranged quincuncially; (D) embryonated egg with characteristic infoldings (IF) of the eggshell; (E) anterior half of infective larva; note the prominent apical organ at the tip of the invaginated proboscis. All scales in $\mathrm{mm}$. AO: apical organ on top of invaginated proboscis; BC: bursa copulatrix (evaginated); CG: cement gland; CR: cement reservoir; DL: dorsal ligament sac; ES: egg-sorting apparatus; FO: floating ovary (ovarian ball); GN: giant nuclei (pair); GP: genital pore; IF: infoldings of eggshell; LE: lemnisci; N: neck; PR: proboscis receptacle; RR: receptacle retractors; SA: acanthor's apical spines; SP: Saefftigen's pouch; SV seminal vesicle; $T$. testes; TE: tegument; UB: uterine bell; UT uterus (the arrow points to an egg inside); VG: vagina enclosed by 2 sphincters; VL: ventral ligament sac 
Since Anguillicola crassus does not appear to show a preference for a specific habitat it may soon become widely spread in Europe.

The distribution of Paratenuisentis ambiguus was correlated with the distribution of its (single) intermediate host. It occurred in the River Weser, where Gammarus tigrinus is highly abundant (Fries \& Tesch $1965)$ and highly infected. It did not occur in the Ruhr lake and almost not in the Elbe estuary, where $G$. tigrinus is absent. The role of $G$. tigrinus as the exclusive intermediate host of $P$. ambiguus has been proved in the field as well as in the laboratory.

Gammarus tigrinus is an indigenous species of mixohaline coastal waters between the St. Lawrence estuary and Florida (Steele \& Steele 1972). Since 1939 it has been recorded from the west coast of England (Sexton 1939) in brackish and polluted waters. Hynes (1955) concluded that it had been introduced through the action of man. It was purposely introduced into the German River Weser (Werra) in 1957 to replace the indigenous gammarid fauna which had disappeared due to pollution (saline sewage; Schmitz 1960, Veh 1975). Since only laboratory offspring of English amphipods were brought into the river (Schmitz 1960) it is unlikely that the parasite was introduced with them.

The high intermediate host specificity of Paratenuisentis ambiguus should prevent a quick spread of this new helminth in Europe. However, Gammarus tigrinus is further expanding its distributional range: Pinkster et al. (1977) reported it from approximately one-third of the Netherlands.

Eoacanthocephalans have had a conspicuous speciation and radiation in North America (Amin 1986); in Europe Paratenuisentis ambiguus is now the second representative of its class.

Acknowledgements. The authors thank Mr and Mrs G. Künzenbach, Mr H. Ludwig (Angelsportverein Bochum) and Mr B. Stemmer (Angelsportverein Votho) for providing eels and Ms C. Brefeld, Ms G. Strieso and Mr H. Löseke for technical assistence. Prof. Lia Paggi generously provided fixed specimens of Anguillicola species. We are also indebted to Dr G. P. Zauke (Universität Oldenburg) for references conceming Gammarus tigrinus. Miss B. Rodust typed the manuscript.

\section{LITERATURE CITED}

Amin, O. (1986). Classification. In: Crompton, D. W. T., Nickol, B. B. (eds.) Biology of the Acanthocephala. Cambridge University Press, Cambridge, p. 27-72

Bullock, W L., Samuel, G. (1975). Paratenuisentis gen. n. for Tanaorhamphus ambiguus Van Cleave 1921 (Acanthocephala), with reconsideration of the Tenuisentidae. J. Parasitol. 61. 105-109

Equsa, S., Kira, K., Wakabayashi, H. (1969). On the occurrence of Anguillicola globiceps Yamaguti, a swimbladder roundworm, in pond-cultured eels. Fish Path. 4: 52-58

Fries, G., Tesch, F. W. (1965). Der Einfluß des Massenvorkommens von Gammarus tigrinus Sexton auf Fische und niedere Tierwelt in der Weser. From: Niedersächsisches Landesverwaltungsamt, Binnenfischerei, Hannover, p. 133-150

Haung, L. F. (1981). Studies on the life-cycle of Anguillicola globiceps. Zoolog. Magaz., Dongwuxue Zazhi 1: 24-25. (Chinese; English summary)

Hine, P. M. (1978). Distribution of some parasites of freshwater eels in New Zealand. N. Z. J. mar. Feshwat. Res. 12: 179-187

Hirose, H., Sekino, T., Egusa, S. (1976). Notes on the egg deposition, larval migration and intermediate host of the nematode Anguillicola crassa parasitic in the swimbladder of eels. Fish Path. 11: 27-31. (Japanese; English summary)

Hynes, H. B. N. (1955). Distribution of some freshwater Amphopoda in Britain. Proc. Int. Ass. Theor. Appl. Limnol. 12: $620-628$

Johnston, T. H., Mawson, P. (1940). Some nematodes parasitic in Australian freshwater fish. Trans. R. Soc. South Aust. 64 : $340-352$

Koie, M. (1988). Parasites in eels, Anguilla anguilla (L.), from a Danish eutrophic lake. J. Helminthol. (in press)

Kuwahara, A., Niimi, A., Itagaki, H. (1974). Studies on a nematode parasitic in the air bladder of the eel. 1. Description of Anguillicola crassa n. sp. (Philometridea, Anguillicolidae). Jap. J. Parasit. 23: 275-279

Möller, H. (1984). Dynamics of fish diseases in the lower Elbe River Helgoländer Meeresunters. 37: 389-411

Moravec, F., Taraschewski H. (1988). Revision of the genus Anguillicola Yamaguti, 1935 (Nematoda: Anguillicolidae) of the swimbladder of eels, including descriptions of two new species, A novaezelandiae sp. $\mathrm{n}$. and A. papernai sp. n. Folia Parasitol. (in press)

Neumann, W (1985). Schwimmblasenparasit Anguillicola bei Aalen. Fischer und Teichwirt 11: 322

Paggi, L., Orecchia, P., Minervini, R., Mattiucci, S. (1982). Sulla comparsa di Anguillicola australiensis Johnston e Mawson, 1940 (Dracunculoidea: Anguillicolidae) in Anguilla anguilla del Lago di Bracciano. Parassitologia 24. 140-144

Peters, G., Hartmann, F. (1986). Anguillicola, a parasitic nematode of the swim bladder spreading among eel populations in Europe. Dis. aquat. Org. 1. 229-230

Pinkster, S., Smit, H., Brands-DeJong, N. (1977). The introduction of the alien amphipod Gammarus tigrinus Sexton, 1939, in the Netherlands and its competition with indigenous species. Crustaceana 4 (Suppl.): 91-105

Rid, L. E. (1973). Helminth parasites of the long-finned eel, Anguilla dieffenbachii, and the short-finned eel, $A$. australis. Mauri Ora 1: 99-106

Samuel, G., Bullock, W. L. (1981). Life cycle of Paratenuisentis ambiguus (Van Cleave, 1921) Bullock and Samuel, 1975 (Acanthocephala: Tenuisentidae). J. Parasitol. 67: 214-217

Schmitz, W. (1960). Die Einbürgerung von Gammarus tigrinus Sexton auf dem europäischen Kontinent. Arch. Hydrobiol. 57: $223-225$

Sexton, E. W. (1939). On a new species of Gammarus (G. tigrinus) from Droitwich district. J. mar. biol. Ass. U. K. 23 : 543-551

Steele, D. H., Steele, V. J. (1972). The biology of Gammarus (Crustacea, Amphipoda) in the northwestern Atlantic. 6. Gammarus tigrinus Sexton. Can. J. Zool. 50: 1063-1068

Taraschewski, H. (1985). Experimental transmission of Acanthocephalus anguillae (Palaeacanthocephala). Z. ParasitKde 71. 825-828 
Van Banning, P., Heermanns, W., Van Willigen, J. A. (1985). Anguillicola crassa, een nieuwe allparasiet in de Nederlandse wateren. Visserij 38: 237-240

Veh, G. M. (1975). Die Salzbelastung der Flüsse im Einzugs- gebiet der Weser. River salinity in the Weser catchment Dt. gewässerkdl. Mitt. (Sonderheft)

Yamaguti, S. (1935). Studies on the helminth fauna in Japan. 9. Nematodes of fishes. 1. Jap. J. Zool. 6:337-386

Responsible Subject Editor: Dr I. Paperna; accepted for printing on November 17, 1987 